\title{
Профілактика неврологічних ускладнень при хірургії торако-абдомінального відділу аорти
}

\author{
Дьогтяр В. В., Чанглі Н. О. \\ ДУ «Науково-практичний медичний центр дитячої кардіології \\ та кардіохірургії М03 України» (Київ)
}

\begin{abstract}
Аневризма аорти - розширення ділянки аорти, зумовлене патологічними змінами сполучнотканинних структур іiі стінок. Незважаючи на застосування різних методів захисту при хірургічному лікуванні аневризми аорти, ризик периопераційних ускладнень залишається високим.

Частота ішемії спинного мозку при операціях на торако-абдомінальному відділі аорти досягає 13\%. Висока частота спінальних ускладнень пояснюється особливостями кровопостачання спинного мозку (CM), гемодинамічними порушеннями та геморагічними ускладненнями під час операції [9].
\end{abstract}

Мета роботи - представити клінічний випадок дренування цереброспінальної рідини під час протезування торако-абдомінальної аорти.

Матеріали та методи. У статті представлено клінічний випадок хірургічного лікування пацієнтки з аневризмою низхідного відділу грудної аорти та черевної аорти, якій було проведено дренування цереброспінальної рідини.

Результати та обговорення. Метою постановки спінального катетера є дренування цереброспінальної рідини для профілактики ішемії спинного мозку та ранніх неврологічних ускладнень (параплегія, парапарез).

Висновки. Пацієнтам при втручаннях на торако-абдомінальному відділі аорти необхідно дренувати цереброспінальну рідину з метою профілактики ранніх неврологічних ускладнень (парапарез, параплегія).

Ключові слова: дренування цереброспінальної рідини, торако-абдомінальна аневризма, параплегія, парапарез.

Аневризма аорти - розширення ділянки аорти, зумовлене патологічними змінами сполучнотканинних структур ії стінок. Аневризми грудного та торако-абдомінального відділів аорти залишаються однією з найважчих проблем у судинній хірургії [1]. Сучасний розвиток діагностики, принципів ведення інтраопераційного та раннього післяопераційного періоду дозволив суттєво знизити летальність і розширити показання до операції. Незважаючи на застосування різних методів ється високим [4].

Важкі неврологічні порушення після операцій на аорті - одне із загрозливих ускладнень. Частота ішемії спинного мозку (CM) при операціях на торако-абдомінальному відділі аорти досягає 13\% [3]. До факторів ризику периопераційного ураження спинного мозку відносять екстрену операцію, розшарування, розповсюдженість патологічного процесу, тривалий час перетиснення аорти, розрив аорти, рівень перетиснення аорти, вік пацієнта і наявність супутніх захворювань $[6,7]$. Висока частота спінальних ускладнень пояснюється особливостями кровопостачання СМ, гемодинамічними порушеннями та геморагічними ускладненнями під час операції [9].

Доцільність моніторингу тиску та дренування цереброспінальної рідини (ЦСР) обгрунтована тим, що при перевищенні тиску ЦСР над венозним досягається критичний тиск закриття, що веде до венозного колапсу.

Мета роботи - представити клінічний випадок дренування цереброспінальної рідини під час протезування торако-абдомінального відділу аорти.

Матеріали та методи. У статті представлено клінічний випадок пацієнтки з аневризмою низхідного відділу грудної аорти, черевної аорти, якій було проведено дренування цереброспінальної рідини.

Результати та обговорення. Пацієнтка Т., 1955 р. н., поступила в ДУ «Науково-практичний медичний центр дитячої кардіології та кардіохірургії МОЗ України» 3 діагнозом: аневризма низхідного відділу грудної аорти та черевної аорти з ознаками пристінкового тромбозу. Невелика тристулкова недостатність. Гіпертонічна хвороба II ст., 2 ст., ризик 2. CH I ст., NYHA II.

Пацієнтці було рекомендовано хірургічне втручання в обсязі: протезування торако-абдомінального відділу аорти судинним графтом в умовах штучного кровообігу.

Передопераційна підготовка пацієнтки включала також встановлення спінального катетера. 
В операційній, після індукції анестезії та введення двопросвітної ендобронхіальної трубки, провели постановку катетера у внутрішню яремну вену для гемодинамічного моніторингу. Артеріальні лінії вводилися як у верхні, так і в нижні кінцівки для контролю проксимальної та дистальної перфузії під час затискання аорти.

Спінальний катетер підключався до датчика інвазивного тиску з метою постійного вимірювання тиску цереброспінальної рідини та можливості пасивного дренування цереброспінальної рідини протягом операції. ЦСР пасивно дренувалася в певних діапазонах тиску: протягом перетиснення Аo $-<10-12 \mathrm{mmHg}$, в ранній післяопераційний період $-<12-15 \mathrm{mmHg}$.

Під час запуску штучного кровообігу тиск спинномозкової рідини становив 6-8 $\mathrm{mmHg}$, церебральна оксиметрія - 79/73, середній артеріальний тиск - 75$80 \mathrm{mmHg}$.

У ВІТ пацієнтка знаходилася на штучній вентиляції легень і на седації дексмедетомідином. Після повного пробудження та впевненості, що пацієнтка знаходиться в ясній свідомості, був проведений неврологічний огляд, який довів відсутність у хворої неврологічного дефіциту. Після цього вона була переведена на самостійне дихання зі стабільною гемодинамікою. Під час перебування у відділенні інтенсивної терапії тиск спинномозкової рідини становив $8-13 \mathrm{mmHg}$.

На другу післяопераційну добу спінальний катетер був видалений.

Тривалість наркозу: 750 хв.

NIRS: L-R 80-90.

Перебування у ВIT: 5 діб.

Тривалість ШВЛ: 15 год.

Тривалість госпіталізації: 22 доби.

Coselli JS та ін. у своєму дослідженні продемонстрували ефективність дренування цереброспінальної рідини: 30-денна летальність становила $5,3 \%(n=4)$ i $2,9 \%(\mathrm{n}=2)$ для досліджуваної та контрольних груп відповідно $[p=0,68]$. У дев'яти пацієнтів $(13,0 \%)$ контрольної групи були параплегія або парапарез. На противагу цьому лише два $(2,6 \%)$ пацієнти в досліджуваній групі мали неврологічний дефіцит [p=0,3]. У жодного пацієнта з дренуванням цереброспінальної рідини не виявлено безпосередньої параплегії.

Підвищення кровоплину до спинного мозку під час та після операції знижує ризик травматизації спинномозкового каналу з 10-20\% до 2,3-10\%. Тим не менше все ще трапляються серйозні ускладнення, включаючи черепно-судинні гематоми [8]. В цілому дренування цереброспінальної рідини привело до $80 \%$ зниження відносного ризику післяопераційного дефіциту. Мета-аналіз 8 досліджень показав зниження післяопераційних неврологічних ускладнень при дренуванні ЦСР $(\mathrm{p}<0,0001)[4]$.

Висновки. Пацієнтам із втручаннями на торако-абдомінальному відділі аорти необхідно дренувати цереброспінальну рідину з метою профілактики ранніх неврологічних ускладнень (парапарез, параплегія).

\section{Література}

1. Braverman AC, et al. (2012). Diseases of the aorta. In RO Bonow et al., eds., Braunwald's Heart Disease: A Textbook of Cardiovascular Medicine, 9th ed., vol. 2, p. 1309-1337. Philadelphia: Saunders.

2. Rooke TW, et al. (2011). 2011 ACCF/AHA Focused update of the guideline for the management of patients with peripheral artery disease (updating the 2005 guideline): A report of the American College of Cardiology Foundation/American Heart Association Task Force on Practice Guidelines. Journal of the American College of Cardiology, 58(19): 2020-2045.

3. Joseph S. Coselli, Jovan Bozinovski and Catherine Cheung. Hypothermic circulatory arrest: safety and efficacy in the operative treatment of descending and thoracoabdominal aortic aneurysms // The annals of thoracic surgery. March, 2008. - Vol. 85. Issue 3. - P. 956-964. 26. London M., Hollenberg M., Wong M. G., et al.

4. Cina CS, Abouzahr L, Arena GO, Lagana A, Devereaux PJ, Farrokhyar F. Cerebrospinal fluid drainage to prevent paraplegia during thoracic and thoracoabdominal aortic aneurysm surgery: A systematic review and meta-analysis. J Vasc Surg 2004; 40:36 - 44.

5. Kuzmik GA, Sang AX, Elefteriades JA. Natural history of thoracic aortic aneurysms. J Vasc Surg 2012;56:565-71.

6. Mortality and Causes of Death, Collaborators (17 December 2014). «Global, regional, and national age-sex specific allcause and cause-specific mortality for 240 causes of death, 1990-2013: a systematic analysis for the Global Burden of Disease Study 2013.“. Lancet. 385: 117-71

7. Patel HJ, Williams DM, Drews JD, et al. A 20-year experience with thoracic endovascular aortic repair. Ann. Surg. 2014;260:691-696.

8. Nancy E. Epstein,Cerebrospinal fluid drains reduce risk of spinal cord injury for thoracic/thoracoabdominal aneurysm surgery: A review Surg Neurol Int. 2018; 9: 48.

9. Woo YJ, Mohler ER III. (Oct. 27, 2015.) Epidemiology, risk factors, pathogenesis and natural history of thoracic aortic aneurysm. 


\title{
Prevention of neurological complications in the surgery of the thoraco-abdominal aorta
}

\author{
Dehtiar V., Chanhli N. \\ GI «Scientific-Practical Children`s Cardiac Center»
}

Aortic aneurysm - enlargement of the aorta, caused by pathological changes in the connective tissue structures of its walls [1]. Despite the application of various methods of protection in the surgical treatment of aortic aneurysms, the risk of perioperative complications remains high [4].

The frequency of ischemia of the spinal cord during operations on the thoraco-abdominal aorta reaches up to $13 \%$ [3]. The high frequency of spinal complications is explained by the features of the blood supply to the spinal cord (CM), hemodynamic disorders and hemorrhagic complications during surgery [9].

The feasibility of monitoring the pressure and drainage of the cerebrospinal fluid (CSF) is based on the fact that when excessive pressure of the CSB over venous blood pressure is reached, the critical closure pressure, which leads to venous collapse, is achieved.

Objective: to present a clinical case of drainage of cerebrospinal fluid during prosthetics of the thoraco-abdominal aorta.

Material and methods. The article presents a clinical case of surgical treatment of a patient with aneurysm of the descending section of the thoracic aorta and abdominal aorta, which was performed drainage of the cerebrospinal fluid.

Results and discussion. The purpose of setting the spinal catheter is drainage of cerebrospinal fluid for the prevention of ischemic spinal cord and early neurological complications (paraplegia, paraparesis).

Increasing the flow to the spinal cord during and after the operation reduces the risk of trembling spinal cord from $2,3-10 \%$ to $10-20 \%$. Nevertheless, serious complications, including craniocerebral hematomas, still occur [8]. In general, drainage of cerebrospinal fluid resulted in a $80 \%$ reduction in the relative risk of postoperative deficiency. A meta-analysis of 8 studies showed a decrease in postoperative neurological complications in drainage of CSF $(\mathrm{p}<0.0001)$ [4].

Conclusions. Patients with intercurrent thoraco-abdominal aorta need to drain the cerebrospinal fluid to prevent early neurological complications (paraparesis, paraplegia).

Key words: drainage of cerebrospinal fluid, thoraco-abdominal aneurysm, paraplegia, paraparesis. 